\title{
Nonclinical Study End Date
}

National Cancer Institute

\section{Source}

National Cancer Institute. Nonclinical Study End Date. NCI Thesaurus. Code C99156.

The date on which the nonclinical trial or study concluded. 